(c) 2017, Elsevier. Licensed under the Creative Commons Attribution-NonCommercial-NoDerivatives 4.0 International

http://creativecommons.org/licenses/by-nc-nd/4.0/

\title{
Energy recovery from waste in India: an evidence-based analysis
}

\author{
J. D. Nixon ${ }^{\mathrm{a}^{*}}$, P. K. Dey ${ }^{\mathrm{b}}$ and S. K. Ghosh ${ }^{\mathrm{c}}$ \\ ${ }^{a}$ Coventry University, Faculty of Engineering, Environment and Computing, Coventry, CV1 \\ 2JH, UK \\ ${ }^{\mathrm{b}}$ Aston Business School, Aston University, Aston Triangle, Birmingham, B4 7ET, UK \\ ${ }^{\mathrm{c}}$ Mechanical Engineering Department, Centre for Quality Management System, Jadavpur \\ University, Kolkata 700032, India \\ *corresponding author, E-mail: jonathan.nixon@coventry.ac.uk; Tel.: 02476887688
}

\begin{abstract}
The uptake of Waste-to-Energy (WtE) in India has not been successful and the majority of plants have failed to sustain operations. There is a lack of detailed on-the-ground research examining the causes of plant failures and the issues regarding the WtE supply chain. Thus, this study set out to identify how WtE practices in India can be improved by gathering and evaluating empirical evidence. Local government officers, industry practitioners and academics involved in waste management in India were consulted, and quantitative data were collected on three case study plants: an incinerator, a gasification plant and a plant cofiring waste with coal. The gathered information was evaluated by making a comparison with two well-established European waste incinerators. The major problem with WtE in India has typically been perceived to be poor source segregation; however, the case study plants highlight that severe contamination has been occurring during transport and storage. In comparison to European incinerators, WtE plants in India have a low capital cost (around 1-2 million $€ / \mathrm{MW}$ ), but total particulate matter emissions (ranging from $65-75 \mathrm{mg} / \mathrm{Nm}^{3}$ ) were found to be a hundred times higher. We conclude with recommendations for delivery contracts, financial incentives and regulations on dumpsites, ash disposal and stack emission measurements.
\end{abstract}

Keywords: Waste-to-Energy (WtE); Municipal Solid Waste (MSW); Energy-from-Waste (EfW); energy policy; waste management. 


\section{Introduction}

In India, around 40 million tonnes of urban Municipal Solid Waste (MSW) is produced every year, and the majority of this waste is sent to unsanitary landfill sites or openly dumped (Hoornweg and Bhada-Tata, 2012; Wolfe and Mahadevia, 2008). Although attempts to improve MSW management in India have been made (e.g. the introduction in 2000 of the MSW Management and Handling Rules), Indian cities are still unable to comply with regulations, and the situation is being exacerbated by rapid urbanisation and population growth (Talyan et al., 2008). The composition of India's MSW is highly variable among urban and rural areas; however, it is typically characterised by a high percentage of organic and inert content. As rag pickers collect recyclable materials from the disposed MSW, the percentage of paper, plastic, glass and metal is often low (Unnikrishnan and Singh, 2010).

One area of growing interest in India is energy recovery from MSW, as it can provide valuable energy services, reduce waste volume and alleviate some of the health and safety hazards associated with current waste management practices. The World Energy Council (2013) reported that the Asia-Pacific region is the fastest growing market (in terms of market size) for waste-to-energy (WtE) and that this is due to developments in China and India. The recent growth in these countries has been spurred by an improved awareness of the hazards and environmental impacts associated with MSW, and increasing energy and land requirements (Yang et al., 2013). It has been estimated that the potential for MSW to energy in India is as high as $1.5 \mathrm{GW}$ and only $2 \%$ of this total has been realised (EAI, 2013). In urban areas of India, the land required for landfill is approximately 1240 hectares per year and the majority of dumpsites are over their capacity. As of 2012, only eight WtE plants have ever been installed in India, along with 279 compost, 172 anaerobic digestion and 29 refusederived fuel (RDF) plants (Planning Commission, 2014).

A number of large scale projects for composting, biomethanation, RDF and WtE have failed in India. Previous attempts at utilising RDF include a 6.6 MW plant in Hyderabad, 6 MW plant in Vijayawada and 500 tonnes per day (tpd) plant in Chandigarh (Kalyani and Pandey, 2014). In 1987, a 3.7 MW WtE plant processing 300 tpd was set up by Mijotecknik in Timarpur, New Delhi; however, it was forced to close within 6 months due to the MSW feedstock having a low calorific value $(550-850 \mathrm{kcal} / \mathrm{kg})$ and high moisture and inert content (Talyan et al., 2008). Plants incinerating MSW in other developing countries have faced similar problems and been discontinued (Abd Kadir, Sharifah Aishah Syed et al., 2013). 
Small-scale biomethanation plants have in general been more successful in India. As of the time of writing, only one WtE plant incinerating just MSW remains in operation in India. Whilst, incineration and gasification have been considered to be more promising than RDF for the thermochemical disposal of MSW in India (Nixon et al., 2013b), integrated material recovery facilities, composting, incineration and landfilling would likely provide the greatest environmental benefits (Erses Yay, 2015).

The WtE industry in developed countries is well-established in comparison to India. Even though issues still exist in developed countries (public opposition, expensive flue gas treatment measurements, disposal of air pollution control residues, and fouling and corrosion of boiler heat exchanger surfaces), the most suitable technologies and processes for treating waste are well-known (European Commission, 2006; Nixon et al., 2013a; Tabasová et al., 2012). However, the issues facing the WtE industry in India are multifarious and many of these issues differ from those encountered in other countries due to different cultural practices and economic climates. Moreover, issues encompassing policy uncertainties, economic barriers, technical difficulties and logistical challenges in India are still not clearly defined or understood.

Several authors have evaluated waste-to-energy practices in India to draw conclusions on the causes of WtE plant failures. Kalyani and Pandey (2014) suggested that MSW processing plant closures have been due to a lack of logistical planning and financing. Chattopadhyay et al. (2009) asserted that the major problem with MSW in Kolkata was poor waste segregation, collection efficiencies and recycling systems. They claimed that the incineration of MSW was not suitable in Kolkata due to the low energy content of MSW $(3350-4200 \mathrm{~kJ} / \mathrm{kg})$ and reported that a tipping fee in the region of 3900-5200 Rs./tonne would be required to make WtE financial viable. Gupta et al. (1998) also claimed that the main issue in India was poor segregation and collection practices, and that incineration was not a suitable option for India. Srivastava et al. (2005) carried out a strengths, weaknesses, opportunities and treats (SWOT) analysis of MSW management in India and gathered stakeholder opinions from government ministries, research institutions and community representatives in Lucknow. They concluded that the weaknesses of MSW management in India were a lack of facilities, adequate transportation and expertise in government. Singh et al. (2011) outlined the potential for energy recovery from MSW using various technologies in India and detailed some of the operating plants in India. However, the challenges that these plants faced were not addressed. 
A comparison of the broader range of different disposal options for waste in India can be found in ref. (Narayana, 2009).

Researchers have typically had to rely on using secondary data to evaluate WtE practices in India. Similarly, authors carrying out research on WtE in other developing countries have focused on reviewing the literature to provide an overview and discussion of the various challenges (Agunwamba, 1998; Cheng and Hu, 2010; Tsai and Chou, 2006; Zhuang et al., 2010). Guerrero et al. (2013) conducted a review of research on the broader issue of waste management in developing countries and they claim that there is a lack of quantitative data. They suggest that there is a need for research to identify the most critical issues through observations of urban areas and surveying a range of relevant stakeholders. Where stakeholder opinions on $\mathrm{WtE}$ in India have been gathered before, there has been a tendency to focus on municipalities and not include the industry's perspective (Srivastava et al., 2005). To the authors' knowledge, there is no study using primary data to make a detailed comparison of WtE plants in India. Furthermore, industrial stakeholder opinions on the issues of WtE in India have not been gathered alongside those of local governments and academics. Thus, there is a lack of detailed on-the-ground information regarding the challenges facing industries and local governments on WtE in India.

As India continues to develop, a significant amount of investment will be made in alternative $\mathrm{WtE}$ facilities. Therefore, there is a need for research to use primary data to characterise and identify the issues that have prevented or will prevent the successful deployment and operation of viable energy recovery facilities. This study aims to address this need by working closely with industries and local governments to provide answers to the following specific research questions:

i. What do industry and government stakeholders perceive the major issues and challenges to be regarding the successful uptake of WtE plants in India?

ii. How does the operations and performance of WtE plants in India compare with established practices in other countries?

iii. What improvements need to be made in order for WtE to become a viable method for energy generation and municipal solid waste management in India? 
Answers to these questions will direct future research and development efforts, and bridge the current gap in reported primary data available in the literature. Furthermore, the study's findings will guide and inform strategic decision making across the entire supply chain, i.e. from energy policymaking and planning to plant operation. The methodology that has been adopted to achieve this study's goals is outlined in the following section. In Section 3, details of a workshop held with Indian stakeholders are outlined, and in Section 4 three case study plants are analysed. The study concludes by providing recommendations to make WtE more sustainable in India.

\section{Methodology}

This empirical study set out to address the first research question by surveying a range of stakeholders from across the WtE supply chain. A workshop was conducted to bring together stakeholders from across India and served as an opportunity for a group of stakeholders to discuss and define the general issues and challenges with implementing $\mathrm{WtE}$ initiatives in India. The participants included 26 officers from Urban Local Bodies (ULBs), 20 industry practitioners and 6 Indian academics to provide a neutral perspective and represent members of the community with expertise in WtE (details of the participating originations can be found in Appendix A of the Supplementary Online Material). The workshop session was carried out in two phases: i) distribution of a survey asking individual stakeholders to provide their opinions on the issues and challenges with WtE in India, cause and effects of these issues and possible solutions and, ii) a group discussion followed by small breakout sessions to capture detailed qualitative information regarding the survey responses provided. During the discussion sessions, the authors acted as observers to record and categorise the types of issues raised into supply side (logistical), conversion issues (technical), economic, social and political. To narrow the focus of the survey, the participants were limited to raising three issues. The results were summarised by recording the number of times a similar issue was identified and reviewing the survey results alongside the information gathered during the discussion sessions.

Whilst it cannot be assumed that the 52 workshop participants fully represented the opinions of WtE stakeholder across the whole of India, they were considered to provide a reliable overview given that they represented a broad range of different industries and municipalities. Thus, it is assumed that a different make-up of the panel would have provided similar results. 
Moreover, the limited panel size stimulated participation and contribution. An improvement to future studies would be to include more selected representatives of the public.

To detail the specific on-the-ground issues faced by operational energy recovery from waste plants in India, three case study plants were identified and subsequently examined (a conventional MSW incinerator, RDF gasification plant and co-firing plant using MSW and RDF). These plants were chosen as they represented the different thermochemical treatment options currently being used and, in most cases, they were the only commercial plants of their type operating in India. As WtE typically refers to the incineration of waste, biochemical treatment processes (e.g. anaerobic digestion) were excluded from the study. To enable the performance of the Indian plants to be fully assessed, and the WtE issues specific to India to be identified, a comparison was made with two well-established European WtE plants located in the UK. The two plants were chosen as they were of a comparable size and had been operating successfully for many years. However, the two plants also demonstrated the variability in operations among plants in Europe. Site visits and interviews were used to gather quantitative and qualitative information at all of the five plants. Technical performance data was gathered from official audit reports and live monitoring devices.

\section{Workshop results}

Figure 1 summarises the number of survey responses raised on particular issues from ULBs, industries and academics, and highlights that social factors were clearly perceived to be the most pressing issues for $\mathrm{WtE}$ in India. Poor source segregation was identified fourteen times and around $25 \%$ of the workshop participants believed poor public engagement to be one of the biggest challenges for WtE in India. This was considered by the majority of the workshop's attendees to be the result of poor education and the public's perception that MSW is the government's problem. However, during the discussion session, one participant asserted that inadequate and unreliable collection services are provided to the public. Thus, they cannot recycle, segregate and dispose of their waste effectively. Whilst public opinion was underrepresented in the workshop, it is interesting that four out of six Indian academics also raised the issue of a lack of public engagement in waste segregation. 


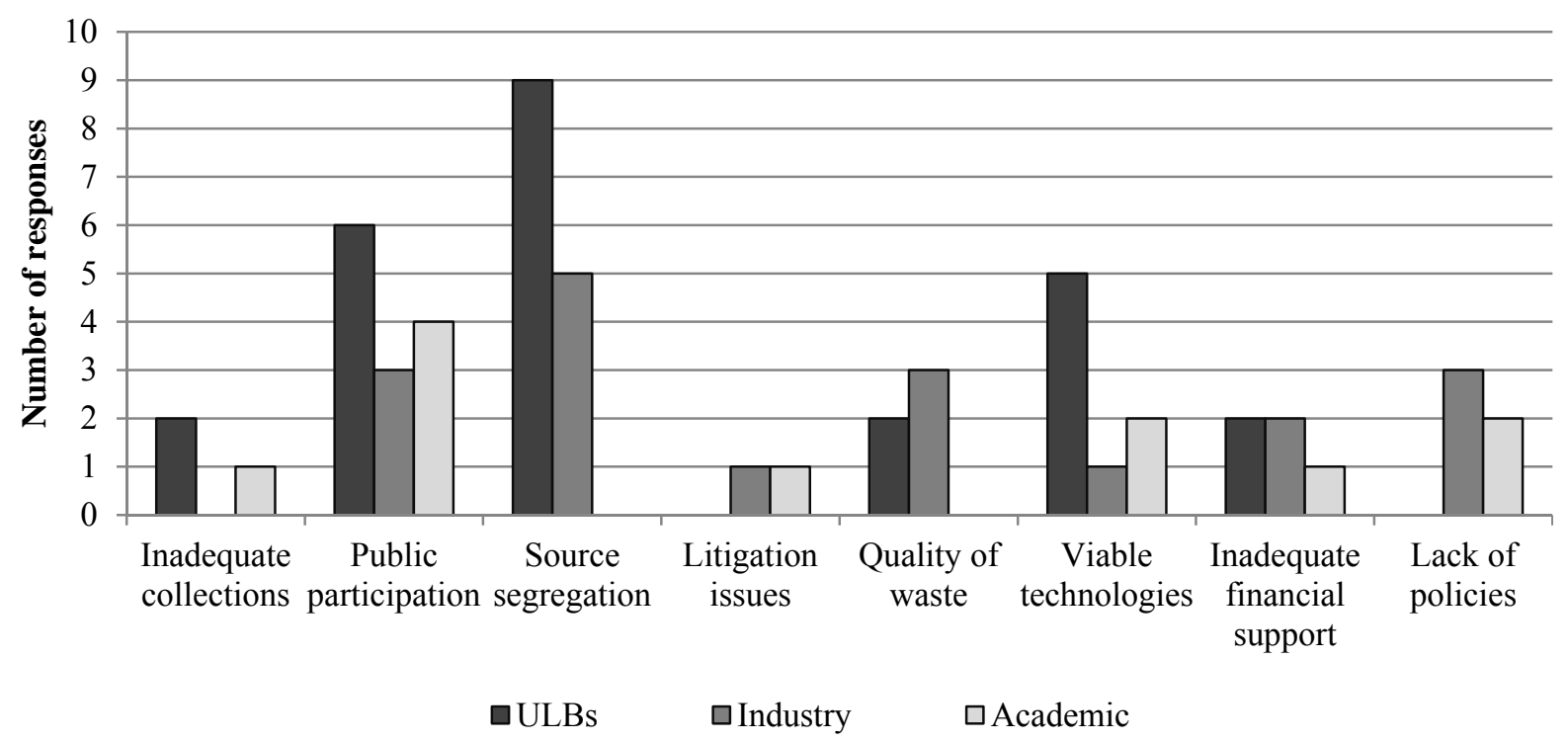

Figure 1: Top issues identified by urban local bodies, industry and academics (Nixon et al., 2015).

Inadequate polices on $\mathrm{WtE}$ in India was a major concern for the industry participants. They remarked that the absence of policies and supportive incentives, such as a gate fee or feed-intariff, makes WtE projects in India economically unviable. The industry stakeholders also felt that ULBs are reluctant to form public private partnerships, share project risks and guarantee a consistent and reliable supply of waste. Conversely, the ULBs commented that central government needs to increase the money available to local bodies to spend on collection services and developing disposal facilities. Political interference was highlighted as a concern for foreign and local investors, as it delays projects and makes risk mitigation difficult. A lack of monitoring and auditing of WtE facilities was raised as an issue and it was claimed that this has resulted in the falsification of emission data and breach of safe operating limits. One participant reported that sometimes truck collections are contaminated by operators with industrial waste to increase waste weight and thus, income received for its delivery.

Technical and financial issues were mostly related to waste quality and financial support. Eight participants believed that new technologies needed to be developed that could effectively process India's variable and high moisture and inert content waste. Several local government officers felt that land limitations were the major challenge for the effective disposal of MSW. Other issues such as inadequate collections, the high cost of WtE, lack of expertise and minimal characterisation data were only raised by a small number of 
participants. Maintenance and operational costs were omitted with only one participant raising the need for capacity building programmes to improve organisation and implementation. Moreover, only one respondent mentioned an environmental issue, which was related to permitting causing project delays. A full record of the survey responses can be found in Appendix B of the Supplementary Online Material, and preliminary results from the workshop have been discussed in a conference proceeding (Nixon et al., 2015)

\section{Case study comparison}

Three Indian and two UK energy recovery from waste plants are now introduced. Process flow diagrams for each plant are shown in Figures $2 a-c$ and 3a-b. The plants' waste treatment processes, financial details and operational characteristics are compared in detail in Table 1. Further details on a range of UK plants can be found in a previous study by the same authors (Nixon et al., 2013a).

1. Shalivahana (MSW) Green Energy Ltd is a $12 \mathrm{MW}$ co-incinerator located in Karimnagar, Andhra Pradesh. The plant runs on a mixture of raw MSW (115 tpd), RDF (33 tpd), biomass wastes (148 tpd) and coal (33 tpd). The plant is located near the largest concentration of rice mill plants in India. Shalivahana Green Energy Ltd collects MSW and produces RDF and compost at three local dumpsites (Shalivahana Green Energy, 2011).

2. Rochem Power Plant is an integrated segregation and gasification plant located in Pune. The segregation plant uses driers, shredders, ferrous and non-ferrous metal collections, trommels and multiple hand separation stages. The plant processes around 300 tonnes per day and obtains 60-70 tpd of compost and 130 tpd of RDF. A gasifier currently processes 20 tpd of RDF and powers a 2.6 MW and 0.4 MW gas engine. The total designed capacity of the plant is $10 \mathrm{MW}$, but the plant is not yet fully operational.

3. Ecopolis is a $16 \mathrm{MW}$ WtE plant commissioned in 2011 and provides electricity to 600,000 homes in New Delhi. The plant is run by Timarpur-Okhla Waste Management Company PVT. Ltd. (Timarpur Okhla Waste Management Company Pvt Ltd, 2011).

4. Tyseley Energy Recovery Facility is a $27 \mathrm{MW} \mathrm{WtE} \mathrm{plant} \mathrm{in} \mathrm{Birmingham,} \mathrm{UK} \mathrm{and} \mathrm{is}$ operated by Veolia Environmental Services. The facility processes 960 tpd of MSW and has an integrated hazardous waste incinerator (14 tpd) that provides feedwater heating (Veolia, 2014). 
5. Coventry and Solihull Waste Disposal Company (CSWDC) is a $17 \mathrm{MW}$ WtE plant in the UK that has been in operation since 1975. The plant process 660 tpd and exports 90,000 MWhel per annum. The site is also integrated with a household waste disposal site receiving 70 tpd with $65 \%$ being recycled, $15 \%$ incinerated and $20 \%$ sent to landfill (CSWDC, 2008).
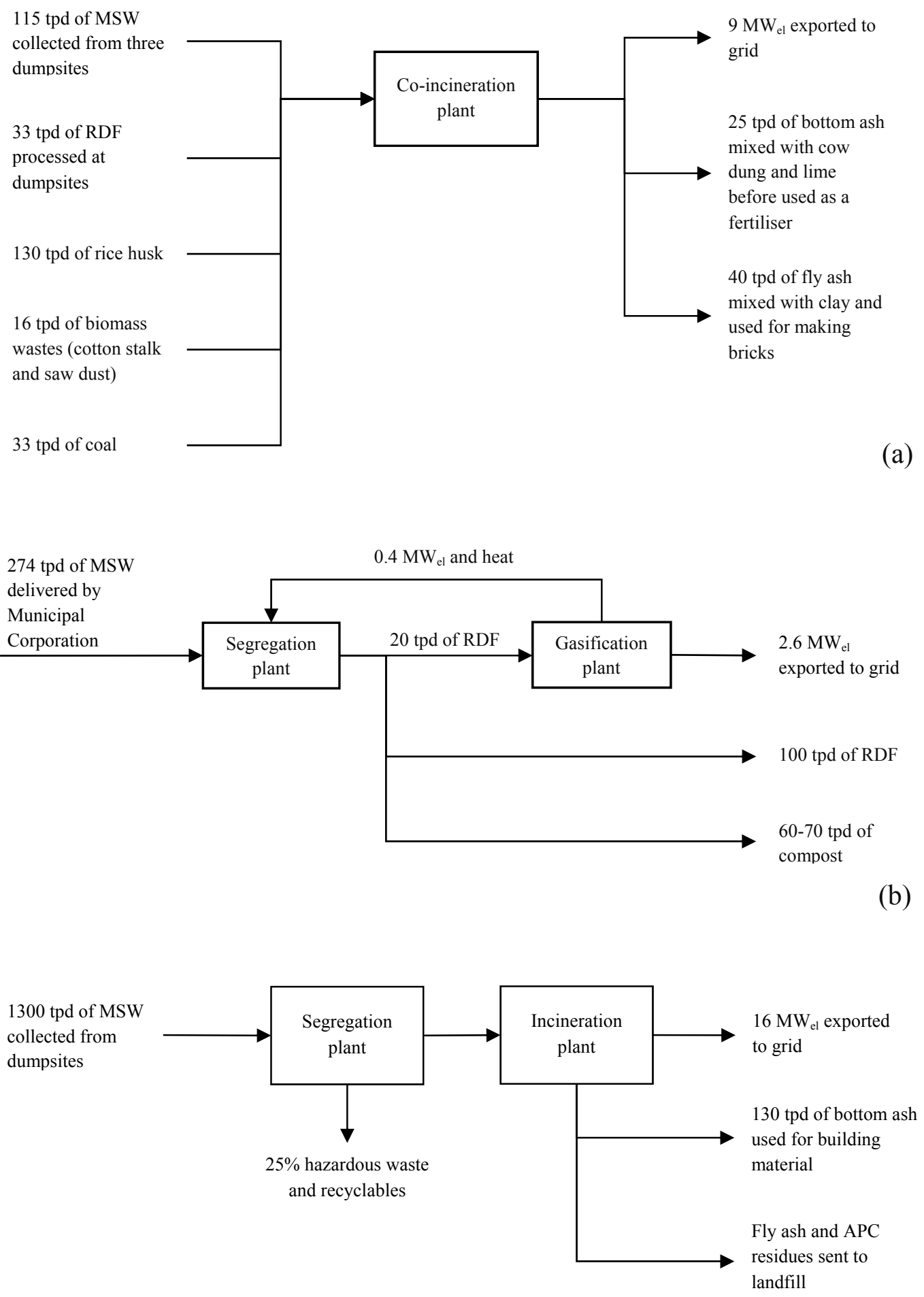

(c) 
Figure 2a-c: Process flow diagram for (a) Shalivahana (MSW) Green Energy Ltd, (b) Rochem Power Plant and (c) Ecopolis.
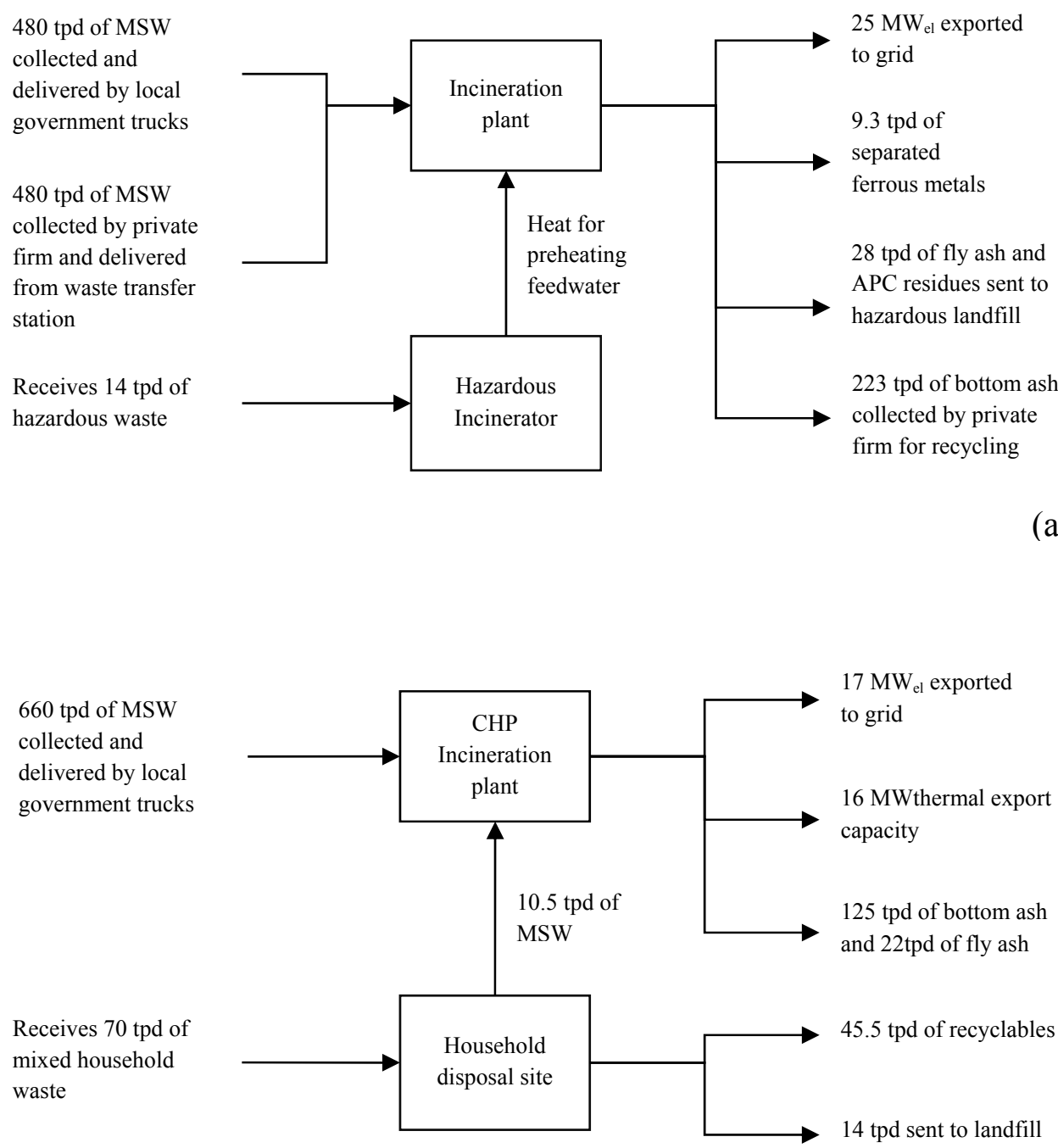

(b)

Figure 3a-b: Process flow diagram for (a) Tyseley Energy Recovery Facility and (b) Coventry and Solihull Waste Disposal Company (CSWDC). 
Table 1: A technical, financial and environmental comparison of three Indian and two UK municipal waste incinerators.

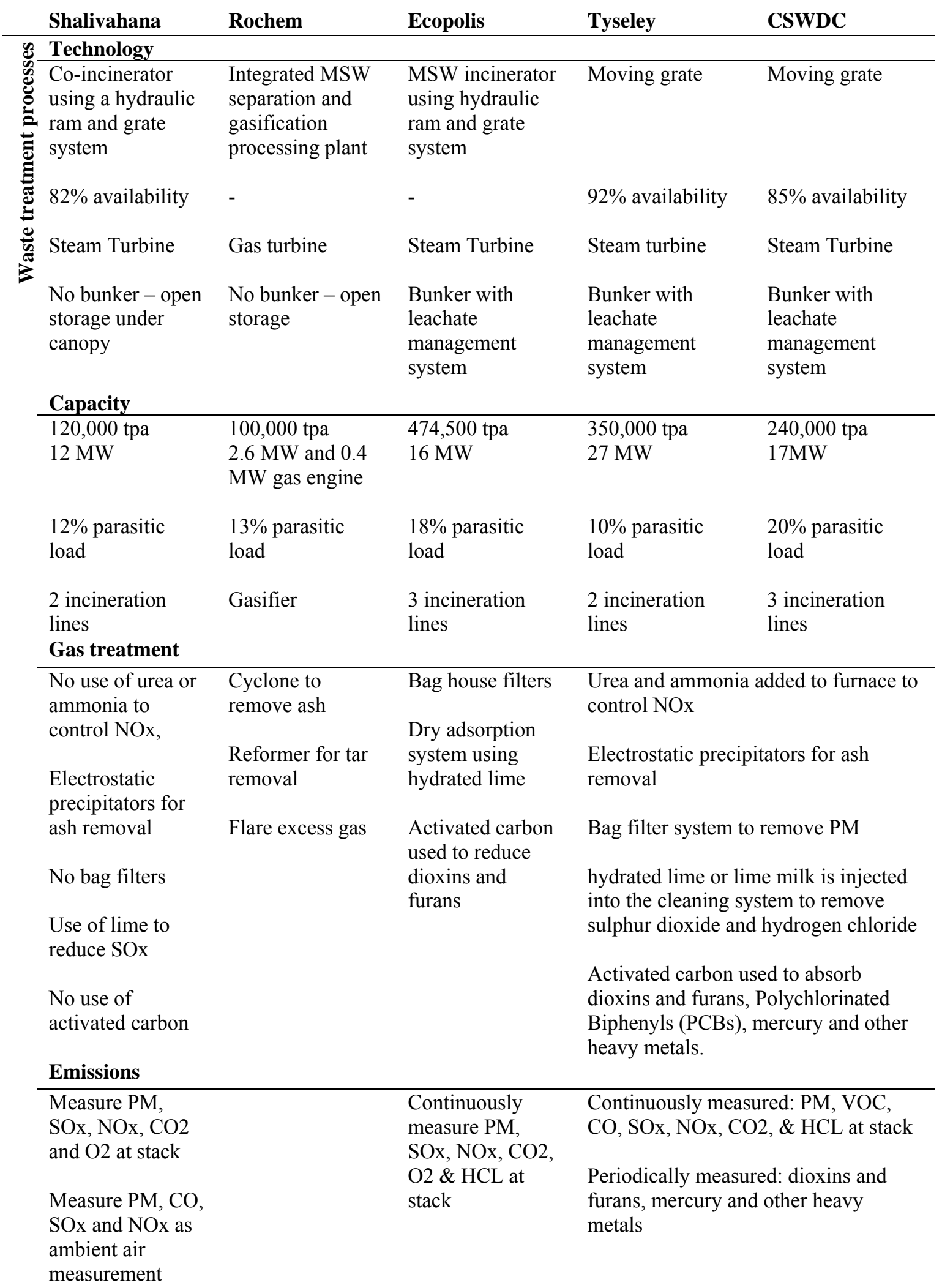


As required by the state Pollution Control Board

As required by the waste incineration directive [29]

Ash

$\begin{array}{ll}8 \% \text { - Bottom ash } & \text { Ash sold for use } \\ \text { is mixed with cow } & \text { in brick making } \\ \text { dung and lime } & \\ \text { and spread on } & \\ \text { fields } & \end{array}$

$10 \%$ - Bottom ash utilized for manufacturing of building material. Volatile organic compounds in ash have to be less $21 \%$ - Bottom $19 \%$ - bottom ash ash is collected by an external company who remove metals and use ash in than $0.01 \%$ road construction

Fly ash and APC residues sent to landfill
$2.4 \%-$ APC residues sent for disposal in hazardous landfill
$3.3 \%-\mathrm{APC}$ residues sent to hazardous landfill mixed with clay

for making bricks

\section{Main issues}

\begin{tabular}{|c|c|c|c|c|}
\hline $\begin{array}{l}\text { Heavily } \\
\text { contaminated } \\
\text { MSW with soil } \\
\text { from intermediate } \\
\text { dumpsite }\end{array}$ & $\begin{array}{l}\text { Low quality and } \\
\text { calorific value of } \\
\text { syngas making } \\
\text { operation difficult }\end{array}$ & $\begin{array}{l}\text { High seasonal } \\
\text { variation in the } \\
\text { waste } \\
\text { composition. } \\
\text { Waste sample }\end{array}$ & $\begin{array}{l}\text { Boiler tube } \\
\text { erosion and leaks }\end{array}$ & $\begin{array}{l}\text { Unable to export } \\
\text { heat. An } \\
\text { automotive } \\
\text { factory } \\
\text { historically } \\
\text { purchased the }\end{array}$ \\
\hline $\begin{array}{l}\text { Difficulties with } \\
\text { obtaining rice } \\
\text { husk in the } \\
\text { months of Jun- } \\
\text { Aug and Mar-Apr } \\
\text { increases the use } \\
\text { of coal. }\end{array}$ & & $\begin{array}{l}\text { often has more } \\
\text { than } 30 \% \\
\text { construction } \\
\text { materials }\end{array}$ & & $\begin{array}{l}\text { heat, but the plant } \\
\text { has now shut } \\
\text { down. } \\
\text { Developing new } \\
\text { heat pipe network } \\
\text { to local town } \\
\text { centre. }\end{array}$ \\
\hline
\end{tabular}

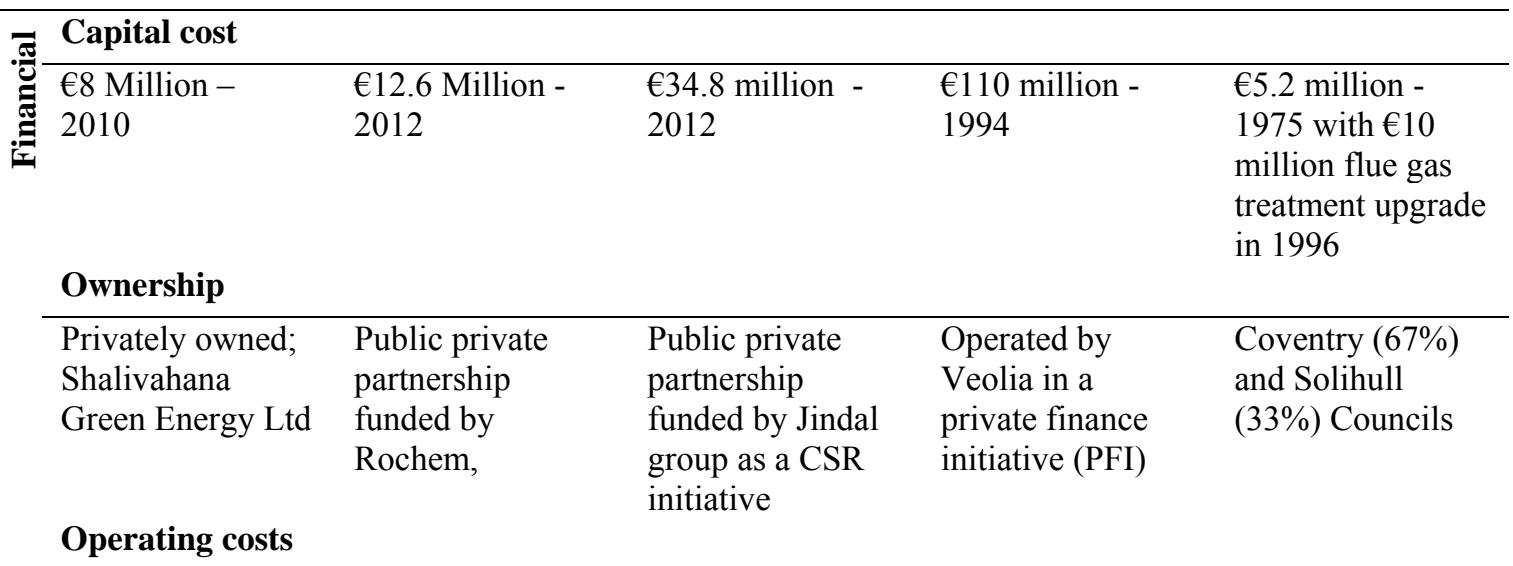




\begin{tabular}{|c|c|c|c|}
\hline $\begin{array}{l}\text { Fixed sale of } \\
\text { electricity at } 5.4\end{array}$ & $\begin{array}{l}\text { The plant will } \\
\text { receive } 4.88\end{array}$ & $\begin{array}{l}\text { Cost of producing } \\
\text { electricity is } 7\end{array}$ & $\begin{array}{l}\text { Additional facility } \\
\text { for incinerating }\end{array}$ \\
\hline Rs./kWh & Rs./kWh & $\begin{array}{l}\text { Rs./kWh but sale } \\
\text { price is only } 2.54\end{array}$ & $\begin{array}{l}\text { hazardous waste } \\
(600 \mathrm{~kg} / \mathrm{hr})-\end{array}$ \\
\hline $\begin{array}{l}\text { Committed to } \\
\text { supply to grid } \\
\text { with } 9 \mathrm{MW} \text {, if it }\end{array}$ & $\begin{array}{l}\text { The plant receives } \\
300 \text { Rs./tonne } \\
\text { from Pune }\end{array}$ & Rs./kWh & $\begin{array}{l}\text { receives premium } \\
\text { gate fee }\end{array}$ \\
\hline $\begin{array}{l}\text { goes below } 70 \% \\
\text { other than for } \\
\text { scheduled shut }\end{array}$ & $\begin{array}{l}\text { Municipal } \\
\text { Corporation } \\
\text { (PMC) }\end{array}$ & & $\begin{array}{l}\text { Electricity sold at } \\
\text { market rates }\end{array}$ \\
\hline $\begin{array}{l}\text { downs they get } \\
\text { fined } 1 \mathrm{Rs} . / \mathrm{kWh} \text {. }\end{array}$ & & & $\begin{array}{l}1-2 \% \text { ferrous } \\
\text { metals recovered } \\
\text { post processing }\end{array}$ \\
\hline $\begin{array}{l}\text { Feedstock } \\
\text { purchase costs: } \\
\text { 4.5 Rs./kg MSW, } \\
\text { 2.4Rs./kg Rice } \\
\text { husk, } \\
1 \text { Rs./kg MSW } \\
\text { (transport), } \\
3 \text { Rs./kg RDF } \\
\text { (separation and } \\
\text { shredding) }\end{array}$ & & & and sold \\
\hline
\end{tabular}
No other incentives (feed in tariff, gate fee, etc.) $\quad$ Receive gate fee that correlates to the

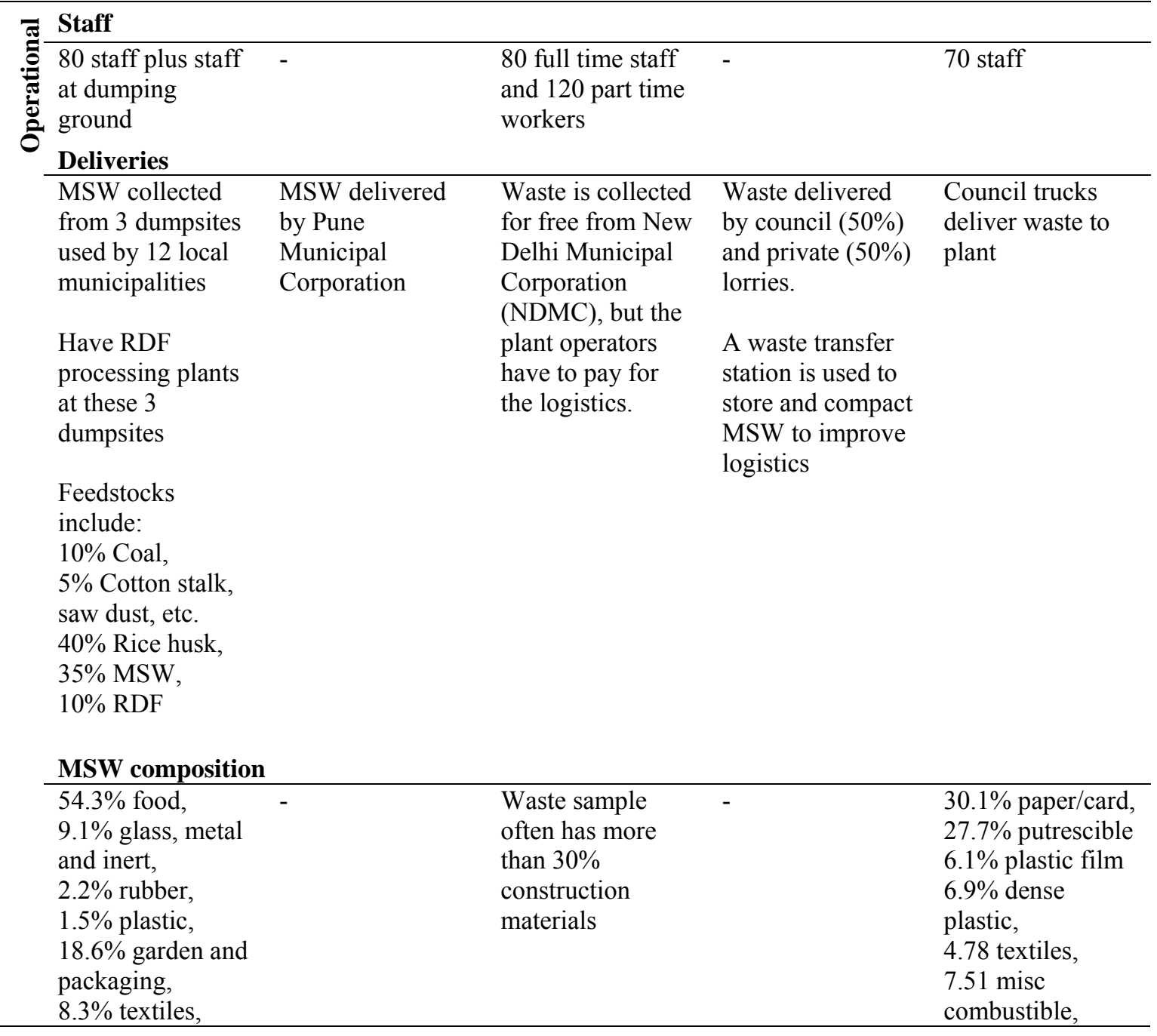




\begin{tabular}{ll}
\hline $2 \%$ paper and & $1.1 \%$ misc non- \\
card & combustible, \\
$4 \%$ wood & $6.5 \%$ glass, \\
products & $6 \%$ metal and \\
(measurements & $4 \%$ fines, \\
taken at source) & hazardous and \\
& electrical \\
\hline
\end{tabular}

\subsection{Waste treatment processes}

The combustion technology being adopted in India is typically a moving grate type system, which is also widely used in Western countries. It is observed that Indian plants are performing a greater amount of pre-processing to separate and shred MSW before incineration. The majority of plants in the UK are not integrated segregation and incineration plants. However, there are exceptions when alternative treatments technologies, such as a fluidised bed system, are used (Nixon et al., 2013a). The system used at Rochem gasifies $\mathrm{RDF}$ at $900{ }^{\circ} \mathrm{C}$ and uses ceramic balls as a heat transfer medium. The Shalivahana plant is co-incinerating MSW with other biomass wastes (45\%) and coal $(10 \%)$ in an attempt to increase the calorific value of the feedstock. Whilst co-firing of coal, RDF and MSW is not practiced in the UK, research has shown that it can reduce $\mathrm{SO}_{2}$ and $\mathrm{NO}_{\mathrm{x}}$ emissions and increase particulate matter concentration (Sami et al., 2001).

Greater differences among Indian and Western plants can be seen in the environmental regulations and emission monitoring data. In Europe, there are strict limits for stack emissions of particulate matter (PM), total organic carbon (TOC), hydrogen chloride ( $\mathrm{HCl})$, carbon monoxide (CO), sulphur oxides (SOx), nitrogen oxides (NOx), dioxins and furans and heavy metals. These are specified in the Waste Incineration Directive (WID)(DIRECTIVE 2000/76/EC), which has been recast within the Industrial Emissions Directive (IED)(DIRECTIVE 2010/75/EC). In India, under the Environmental (Protection) Act, national ambient air quality standards are provided (CPCB, 2009). Table 2 shows the Indian national ambient air quality standards and air quality measurements at Shalivahana. Although industry specific standards for stack emission limits are stated for common hazardous waste incinerators (CPCB, 2008b), there are no industry standards for the incineration of MSW. Indian WtE plants only have to comply with a consent to operate certificate, which is granted by the state government pollution control board.

Table 2: National ambient air quality standards (CPCB, 2009) and Shalivahana's ambient air measurements provided by a pollution control board third party analysis. 


\begin{tabular}{|c|c|c|c|c|}
\hline & $\begin{array}{r}\text { Time } \\
\text { weighted } \\
\text { average }\end{array}$ & $\begin{array}{r}\text { Industrial, } \\
\text { residential, } \\
\text { rural and other } \\
\text { area } \\
\left(\mu \mathrm{g} / \mathrm{m}^{3}\right)\end{array}$ & $\begin{array}{r}\text { Ecologically } \\
\text { sensitive area } \\
(\text { notified by } \\
\text { central govt. } \\
\left(\mu \mathrm{g} / \mathrm{m}^{3}\right) \\
\end{array}$ & $\begin{array}{r}\text { Measured } \\
\text { Shalivahana, } \\
\text { India } \\
\left(\mu \mathrm{g} / \mathrm{m}^{3}\right)\end{array}$ \\
\hline \multirow{2}{*}{ Sulphur Dioxide $\left(\mathrm{SO}_{2}\right)$, } & Annual & 50 & 20 & * \\
\hline & 24 hours & 80 & 80 & $7-10$ \\
\hline \multirow{2}{*}{ Nitrogen dioxide $\left(\mathrm{NO}_{2}\right)$, } & Annual & 40 & 30 & * \\
\hline & 24 hours & 80 & 80 & $10-14$ \\
\hline \multirow{2}{*}{ Particulate matter $\left(\mathrm{PM}_{10}\right)$} & Annual & 60 & 60 & * \\
\hline & 24 hours & 100 & 100 & $49-61$ \\
\hline \multirow{2}{*}{ Particulate matter $\left(\mathbf{P M}_{2.5}\right)$} & Annual & 40 & 40 & * \\
\hline & 24 hours & 60 & 60 & $30-35$ \\
\hline \multirow{2}{*}{ Carbon monoxide (CO) } & 8 hours & 2 & 2 & * \\
\hline & 1 hour & 4 & 4 & * \\
\hline
\end{tabular}

${ }^{*}$ Data unavailable or not provided

Table 3 shows that Indian WtE plants have fewer and less strict stack emission limits in comparison to European plants. Shalivahana has to only monitor PM, $\mathrm{SOx}, \mathrm{NOx}, \mathrm{CO}_{2}$ and $\mathrm{O}_{2}$ emissions at its stack, and the plant at Rochem is still in a trail phase and does not yet have any emission limits as per a consent to operate certificate. The limits stated in Ecopolis' consent to operate certificate are significantly higher than European emission limits; For example, the particulate matter emission limit is ten times higher than the UK plants; measured particulate matter emissions have also been a hundred times higher. Not all of the emission limits and measured emissions were made available by Ecopolis and Shalivahana. However, it has been claimed that dioxin emissions of 12.413 and $2.758 \mathrm{ng} / \mathrm{m}^{3}$ have been measured at Ecopolis' two boiler stacks, which is well above a $0.1 \mathrm{ng} \mathrm{TEQ} / \mathrm{m}^{3}$ limit. It has been further claimed that ash is not tested for toxicity (Business Standard, 2014). There is also a lack of heavy metal emissions monitoring at the plants in India; heavy metal emission limits specified by the WID are in the region of $0.05-0.5 \mathrm{mg} / \mathrm{m}^{3}$. It is important to note that the Waste Incineration Directive does also states half hourly average values, which are more lenient than daily average limit values. There are also variations within the WID for different plant set-ups and emission limits to water that are not compared or discussed in this paper.

Table 3: Comparison of emission limits and typical emission measurements at WtE plants in India and the UK (CPCB, 2008a; CSWDC, 2009; Defra, 2010; Timarpur Okhla Waste Management Company Pvt Ltd, 2011; Veolia, 2012). 


\begin{tabular}{|c|c|c|c|c|c|c|c|}
\hline $\begin{array}{l}\text { Emission } \\
\text { parameter }\end{array}$ & $\begin{array}{r}\text { Limits } \\
\text { UK/ } \\
\text { Europe }^{\mathrm{a}} \\
\left(\mathrm{mg} / \mathrm{Nm}^{3}\right)\end{array}$ & $\begin{array}{r}\text { Measured } \\
\text { Tysley } \\
\text { UK } \\
\left(\mathrm{mg} / \mathrm{Nm}^{3}\right)\end{array}$ & $\begin{array}{r}\text { Measured } \\
\text { CSWDC } \\
\text { UK } \\
\text { b }\left(\mathrm{mg} / \mathrm{Nm}^{3}\right) \\
\end{array}$ & $\begin{array}{r}\text { Limits } \\
\text { Ecopolis } \\
\text { India }^{\text {a }} \\
\left(\mathrm{mg} / \mathrm{Nm}^{3}\right)\end{array}$ & $\begin{array}{r}\text { Measured } \\
\text { Ecopolis } \\
\text { India } \\
\left(\mathrm{mg} / \mathrm{Nm}^{3}\right)\end{array}$ & $\begin{array}{r}\text { Limits } \\
\text { Shalivahana } \\
\text { India }^{\text {a }} \\
\left(\mathrm{mg} / \mathrm{Nm}^{3}\right) \\
\end{array}$ & $\begin{array}{r}\text { Measured } \\
\text { Shalivahana } \\
\text { India } \\
\left(\mathrm{mg} / \mathrm{Nm}^{3}\right) \\
\end{array}$ \\
\hline $\begin{array}{l}\text { Total } \\
\text { particulate } \\
\text { matter (PM) }\end{array}$ & 10 & 0.8 & 0.7 & 150 & 75 & 100 & 64 \\
\hline $\begin{array}{l}\text { Total } \\
\text { Organic } \\
\text { Carbon } \\
\text { (TOC) }\end{array}$ & 10 & 0.8 & 1 & $\mathrm{n} / \mathrm{a}$ & $\mathrm{n} / \mathrm{a}$ & $\mathrm{n} / \mathrm{a}$ & $\mathrm{n} / \mathrm{a}$ \\
\hline $\begin{array}{l}\text { Hydrogen } \\
\text { Chloride } \\
\text { (HCl) }\end{array}$ & 10 & 5 & 1.5 & 50 & 18.5 & $\mathrm{n} / \mathrm{a}$ & $\mathrm{n} / \mathrm{a}$ \\
\hline $\begin{array}{l}\text { Carbon } \\
\text { Monoxide } \\
\text { (CO) }\end{array}$ & 50 & 11 & 10 & $\mathrm{n} / \mathrm{a}$ & $\mathrm{n} / \mathrm{a}$ & $\mathrm{n} / \mathrm{a}$ & $\mathrm{n} / \mathrm{a}$ \\
\hline $\begin{array}{l}\text { Sulphur } \\
\text { Dioxide } \\
\left(\mathrm{SO}_{2}\right)\end{array}$ & 50 & 5 & 32.5 & * & * & * & * \\
\hline $\begin{array}{l}\text { Oxides of } \\
\text { Nitrogen } \\
\text { (NOx) }\end{array}$ & 200 & 150 & 170 & 450 & 300 & * & * \\
\hline
\end{tabular}

${ }^{\text {a }}$ Daily average limits

* Data unavailable or not provided

At Shalivahana, bottom ash is mixed with cow dung and lime, and spread on fields, and fly ash is mixed with clay and made into bricks. At Ecopolis, providing the volatile organic compounds are less than $0.01 \%$, the bottom ash is used as an aggregate. Fly ash and air pollution control (APC) residues are sent to landfill. In Europe, bottom ash is used in road construction and foundations, where there is no risk of contact with groundwater. A large proportion of bottom ash is still sent to landfill across Europe, due to the cost and difficulty of reducing leaching. However, there is no standard or legislation for the use of bottom ash in Europe and leachate limits are variable (ISWA, 2006). Fly ash in the UK is typically combined with air pollution control residues and sent to hazardous landfill or used for acid waste neutralisation.

\subsection{Financial}

The lack of supportive policies for WtE in India makes it difficult to operate financially viable plants. Whereas plants in Western countries are paid in the region of $€ 100 /$ tonne to take MSW, Indian plants typically receive no gate fee and even have to pay the logistical costs of collecting MSW. The lack of a gate fee and feed in tariff has resulted in Ecopolis having to sell electricity at around a third of the cost to produce a unit of electricity, e.g. the current cost of producing electricity at Ecopolis is just over Rs. $7 / \mathrm{kWh}(0.09 € / \mathrm{kWh})$, 
whereas the sale price is only $2.54 \mathrm{Rs} . / \mathrm{kWh}(0.03 € / \mathrm{kWh})$. However, low labour costs and fewer flue gas treatment processes have resulted in the capital cost of WtE plants in India being relatively low. The typical cost of European WtE plants is in the region of 4 million $€ / \mathrm{MW}$ and the capital cost of $\mathrm{WtE}$ plants in India range from 0.66 (Shalivahana) to 2.175 (Ecopolis) million $€ / \mathrm{MW}$. The capital cost of the German built $3 \mathrm{MW}$ gasification plant at Rochem was higher at 4.2 million $€ / \mathrm{MW}$.

\subsection{Operational}

The methods for delivering MSW to energy recovery facilities in India are variable. Shalivahana and Ecopolis are able to collect MSW from dumpsites for free, thus they only have to pay logistical costs. Figure 4 shows highly contaminated MSW at a dumpsite near Shalivahana, and Shalivahana has set up segregation plants at three different dumpsites to improve MSW quality and produce RDF and compost (see Figure 5). However, this adds $€ 38 /$ tonne to the cost of the MSW feedstock. Interestingly, the composition of MSW from households in Karimnagar (source of MSW for the Shalivahana plant) was found to be of a reasonable quality ( $<10 \%$ inert content). However, the MSW being processed at Shalivahana is still highly contaminated with soil, even after segregation. Shalivahana also faces difficulties with obtaining a consistent supply of rice husk and other biomass wastes. The quantity of coal being incinerated at Shalivahana is variable and depends on the energy content of the other feedstocks being processed. Ecopolis suffers from similar problems regarding waste composition. They have characterised their MSW to have often more than a $30 \%$ content of construction waste, which makes it difficult to process. Rochem has an unusual situation in India, as MSW is delivered to them by Pune Municipal Corporation (PMC). However, the lack of an appropriate storage management system has resulted in a large build-up of MSW outside the plant (see Figure 6). PMC has also taken the initiative of introducing a small gate fee (3.8€/tonne), due to a lack of space within its boundaries for dumpsites. Numerous anaerobic digesters have been installed throughout Pune to process household food, restaurant and market wastes to power streetlights. Many ULBs in India are struggling to find space to locate new landfill sites and this should drive the uptake of WtE facilities as they have a far more compact footprint in comparison to landfill sites. 


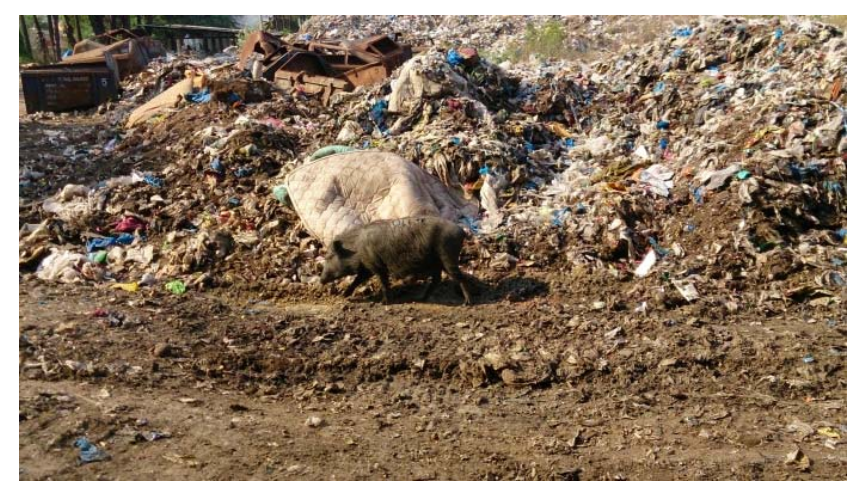

Figure 4: MSW contaminated with soil at a dumpsite near Karimnagar, India, which is collected and incinerated by Shalivahana (MSW) Green Energy Ltd.

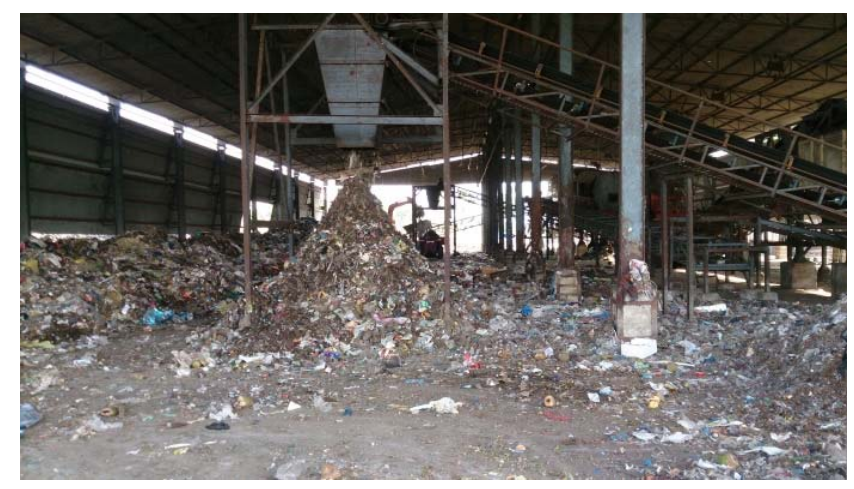

Figure 5: A sorting plant set up at a dumpsite near Karimnagar, India.

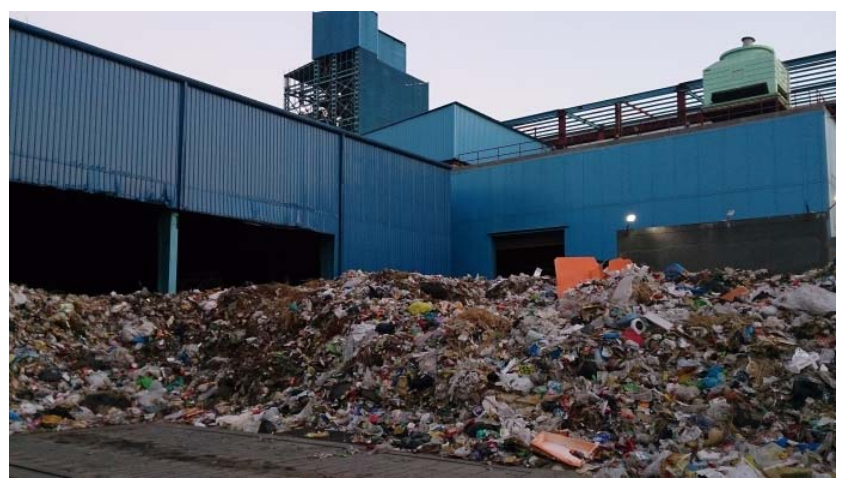

Figure 6: Waste at entrance to Rochem Power Plant

\section{Discussion}

The survey results were interesting as they suggested that both industry and government stakeholders perceived the major challenge regarding waste-to-energy in India to be the lack of source segregation and public participation. These issues have also been discussed throughout the literature on WtE in India (Chattopadhyay et al., 2009). However, the group discussion sessions and evaluations of the case study plants highlighted that contamination of MSW, once it has left its source, is also a major problem in India. Sharholy et al. (2008) reported on the high ash and soil content in Indian MSW and attributed this to road sweepers, but this study reveals that contamination is also occurring throughout the supply chain. It is 
occurring during transport (malpractice by truck operators), storage at intermediate and final dumpsites (MSW mixed with ground soil and contaminated by fly-tipping), and on-site processing at the $\mathrm{WtE}$ plant (no bunker or storage management system being used, e.g. lack of roofing, concreted floor and drainage system). Storage of MSW in gateways and neighbouring fields is particularly poor practice by plants in India. There is also a requirement to better characterise MSW throughout the WtE supply chain-rather than just at source or at plant — in order to identify and reduce sources of contamination.

Ash usage and emission limits at the Indian case study plants differed significantly in comparison to practices at European plants. The use of bottom ash in India for horticulture and building construction is a concern given that it can contain pollutants and contaminate soil and water through leaching. As fly ash can contain heavy metals and other harmful trace elements (Lima et al., 2008), its use for brick making and disposal in unsanitary or even standard landfill sites in India is also a concern. Purification of bottom ash should be carried out that involves sieving, weathering, crushing, sifting, magnetic separation and chemical stabilisation before testing levels of sulphate, chlorine, sodium and heavy metals. Details of the case study plants' emissions and operating regulations were presented in Section 4, and highlighted that emission limits need to be standardised and revised for the incineration of non-hazardous MSW. Measured total particulate matter emissions and emission limits in India were found to be around one hundred and ten times higher, respectively, than those in Europe Furthermore, some stakeholders at the workshop claimed that plants are breaching emission limits and falsifying data. Thus, WtE plants should be more carefully regulated and transparent with their emission measurements.

With the exception of the 2000 MSW Management and Handling Rules, there is a lack of policies relating to WTE in India. Having surveyed stakeholders in the field of WtE and evaluated operational plants in India, a number of recommendations are made to guide future policies and make $\mathrm{WtE}$ a viable option for India:

1. Introduce contracts for waste collections and deliveries

With only $70 \%$ of MSW being collected in India there is scope for significant improvement (Unnikrishnan and Singh, 2010). It is surprising that some WtE plants have struggled to obtain a consistent supply of MSW, given the vast qualities available in India. WtE plants need to have contracts from ULBs for the provision of waste, so that they can operate effectively.

2. Control and regulate storage sites to reduce contamination 
Primary waste collection methods in India are variable and depend on the location. Many regions lack door-to-door collections with authorities only collecting waste from informal street collection points or intermediate dumpsites. Small cart collections (funded by homeowners) or lorry collections (funded by ULBs) are utilized in some areas. Small cart waste collections are dumped at intermediate dumpsites, and a secondary large lorry collection takes the waste to a large dumpsite located outside the city or town centre. This supply chain needs to be drastically revised and regulated to improve sanitation and reduce contamination with soil, road sweepings and industrial waste.

3. Improve education, public awareness and participation

Better awareness of handling MSW from the public will improve source segregation and reduce open dumping. Furthermore, there is a need for expertise in local and central government to promote improved practices in MSW management in India. Greater knowledge on the subject will also increase market activities and sustainable investments and developments.

4. Provide additional disposal facilities

A lack of disposal facilities and collections is resulting in open dumping. Collaboration and communication among central governments, ULBs and plant operators is needed to reduce contamination and improve source segregation.

5. More funds from central government to ULBs and introduce supportive mechanisms

In developed countries, gate fees $(\approx € 100 / \mathrm{t})$ have proven successful and research has shown that even a relatively low gate fee $(\approx € 50 / \mathrm{t})$ would make $\mathrm{WtE}$ in India financially viable (Chattopadhyay et al., 2009; Nixon et al., 2013a). This will improve the financial viability of WtE plants, and enable flue gas treatment equipment to be installed and activated carbon and urea to be used to reduce particulate matter, dioxins and NOx emissions.

6. Revise stack monitoring emissions limits and regulations on the use of ash

Industry specific standards need to be introduced for the incineration of non-hazardous MSW. In additional to national ambient air quality standards, stack emission measurements should be mandatory-including $\mathrm{TOC}, \mathrm{HCl}$, and $\mathrm{CO}$ emissions among others - and made available in the public domain. Whilst ash content is being monitored, its use should be revised to minimize the chance of leaching and ground water and soil contamination.

\section{Conclusion}

There is a pressing need in India to make waste-to-energy projects more viable, and this study identified some of the main issues and barriers that have prevented their greater deployment 
in India. A workshop with industry and government stakeholders highlighted that societal problems were perceived to be the most pressing issue. Three Indian case study plants, which formed the majority of commercial plants thermally processing MSW in India, were also examined. By drawing comparisons with European plants, specific issues were identified that have not been fully explored before. These issues included a lack of onsite storage and bunker management systems, regulations on the disposal of ash, emission limits for heavy metals and emissions monitoring. The workshop and case study approach taken in this study enabled a number of recommendations to be made that can be used to guide and inform new policies and research on $\mathrm{WtE}$ in India. We believe that more primary research studies of this type are required in other developing countries to gather quantitative and qualitative data, as this can better illuminate some of the current challenges regarding the sustainability of wasteto-energy.

\section{Acknowledgements}

The authors would like to acknowledge the assistance from Shalivahana (MSW) Green Energy Ltd, Rochem Power Plant, Ecopolis, Biogas plants Mailham, Pune Municipal Corporation, Govt of Andhra Pradesh, Govt of Telengana and the International Society of Waste Management, Air and Water (ISWMAW). We would also like to acknowledge the funding from the British Council, UK and UGC, India under a UKIERI UGC Thematic Partnership.

\section{Figures and tables}

Figure 1: Top issues identified by urban local bodies, industry and academics.

Figure 2a-c: Process flow diagram for (a) Shalivahana (MSW) Green Energy Ltd, (b) Rochem Power Plant and (c) Ecopolis.

Figure 3a-b: Process flow diagram for (a) Tyseley Energy Recovery Facility and (b) Coventry and Solihull Waste Disposal Company (CSWDC).

Figure 4: MSW at a dumpsite near Karimnagar, India, which is collected and incinerated by Shalivahana (MSW) Green Energy Ltd.

Figure 5: A sorting plant set up at a dumpsite near Karimnagar, India.

Figure 6: Waste at entrance to Rochem Power Plant

Table 1: A technical, financial and environmental comparison of three Indian and two UK municipal waste incinerators. 
Table 2: National ambient air quality standards (CPCB, 2009) and Shalivahana's ambient air measurements provided by a pollution control board third party analysis.

Table 3: Comparison of emission limits and typical emission measurements at WtE plants in India and the UK (CPCB, 2008a; CSWDC, 2009; Defra, 2010; Timarpur Okhla Waste Management Company Pvt Ltd, 2011; Veolia, 2012).

\section{References}

Abd Kadir, Sharifah Aishah Syed, Yin, C., Rosli Sulaiman, M., Chen, X., El-Harbawi, M., 2013. Incineration of municipal solid waste in Malaysia: Salient issues, policies and waste-toenergy initiatives, Renewable and Sustainable Energy Reviews 24, 181-186.

Agunwamba, J., 1998. Solid waste management in Nigeria: problems and issues, Environ. Manage. 22, 849-856.

Business Standard, 2014. The tangled tale of Jindal's waste-to-energy project. Available at: http://www.business-standard.com/article/specials/the-tangled-tale-of-jindal-s-waste-toenergy-project-113060300039 1.html (Accessed 8th March 2016).

Chattopadhyay, S., Dutta, A., Ray, S., 2009. Municipal solid waste management in Kolkata, India - A review, Waste Manage. 29, 1449-1458.

Cheng, H., Hu, Y., 2010. Municipal solid waste (MSW) as a renewable source of energy: Current and future practices in China, Bioresour. Technol. 101, 3816-3824. doi: http://dx.doi.org/10.1016/j.biortech.2010.01.040.

CPCB, 2009. National Ambient Air Quality Standards, Central Pollution Control Board Notification. Available at: http://cpcb.nic.in/National_Ambient_Air_Quality_Standards.php (Accessed 24th November 2016).

CPCB, 2008a. The Environment (Protection) Rules, 1986 Common hazardous waste incinerator. Available at: http://www.cpcb.nic.in/Industry-Specific-Standards/Effluent/5171.pdf (Accessed 3rd November 2016). 
CPCB, 2008b. Industry Specific Standards. Available at:

http://www.cpcb.nic.in/Industry_Specific_Standards.php (Accessed 29th October 2016).

CSWDC, 2009. The Coventry and Solihull Waste Disposal Company Waste to Energy Plant. Annual Performance Report.

CSWDC, 2008. Recovering Energy from Waste. Available at: http://www.cswdc.co.uk/ (Accessed 3rd November 2016).

Defra, 2010. Environmental Permitting Guidance, The Waste Incineration Directive.

DIRECTIVE 2000/76/EC, Council Directive (EC) DIRECTIVE 2000/76/EC of 4 December 2000. L 332/91, Official Journal of the European Communities.

DIRECTIVE 2010/75/EC, Council Directive (EC) DIRECTIVE 2010/75/EC of 24 November 2010. L 334/1, Official Journal of the European Communities.

EAI, 2013. India MSW to Energy- Status, Opportunities and Bottlenecks, Ministry of New and Renewable Energy. Available at: http://www.eai.in/ref/wp/india-msw-to-energy.html (Accessed 8th March 2016).

Erses Yay, A.S., 2015. Application of life cycle assessment (LCA) for municipal solid waste management: a case study of Sakarya, J. Clean. Prod. . doi: http://dx.doi.org/10.1016/j.jclepro.2015.01.089.

European Commission, 2006. Integrated Pollution Prevention and Control, Reference Document on Best Available Techniques for the Waste Treatments Industries.

Guerrero, L.A., Maas, G., Hogland, W., 2013. Solid waste management challenges for cities in developing countries, Waste Manage. 33, 220-232. doi: http://dx.doi.org/10.1016/j.wasman.2012.09.008.

Gupta, S., Mohan, K., Prasad, R., Gupta, S., Kansal, A., 1998. Solid waste management in India: options and opportunities, Resour. Conserv. Recycling 24, 137-154.

Hoornweg, D., Bhada-Tata, P., 2012. What a Waste: A Global Review of Solid Waste Management. World Bank, Washington, DC. 
ISWA, 2006. Management of Bottom Ash from WTE Plants. International Solid Waste Association.

Kalyani, K.A., Pandey, K.K., 2014. Waste to energy status in India: A short review, Renewable and sustainable energy reviews 31, 113-120.

Lima, A.T., Ottosen, L.M., Pedersen, A.J., Ribeiro, A.B., 2008. Characterization of fly ash from bio and municipal waste, Biomass Bioenergy 32, 277-282.

Narayana, T., 2009. Municipal solid waste management in India: From waste disposal to recovery of resources? Waste Manage. 29, 1163-1166.

Nixon, J., Wright, D., Dey, P., Ghosh, S., Davies, P., 2013a. A comparative assessment of waste incinerators in the UK, Waste Manage. 33, 2234-2244.

Nixon, J.D., Dey, P.K., Ghosh, S.K., Davies, P.A., 2013b. Evaluation of options for energy recovery from municipal solid waste in India using the hierarchical analytical network process, Energy 59, 215-223.

Nixon, J.D., Wright, D., Dey, P.K., Scott, J.A., Sagi, S., Ghosh, S.K., 2015. Issues and challenges of implementing waste-to-energy practices in India. In Renewable Energy in the Service of Mankind Vol I, Selected Topics from the World Renewable Energy Congress WREC 2014, Sayigh, A., Ed.; Springer International Publishing, 65-74

Planning Commission, 2014. Report of the Task Force on Waste to Energy (Volume I), Government of India. Available at: http://planningcommission.nic.in/reports/genrep/rep_wte1205.pdf (Accessed 8th March 2016).

Sami, M., Annamalai, K., Wooldridge, M., 2001. Co-firing of coal and biomass fuel blends, Progress in energy and combustion science 27, 171-214.

Shalivahana Green Energy, 2011. MSW Projects in Operation. Available at: http://www.shalivahanagroup.com (Accessed 8th March 2016). 
Sharholy, M., Ahmad, K., Mahmood, G., Trivedi, R.C., 2008. Municipal solid waste management in Indian cities - A review, Waste Manage. 28, 459-467.

Singh, R.P., Tyagi, V.V., Allen, T., Ibrahim, M.H., Kothari, R., 2011. An overview for exploring the possibilities of energy generation from municipal solid waste (MSW) in Indian scenario, Renewable and Sustainable Energy Reviews 15, 4797-4808.

Srivastava, P.K., Kulshreshtha, K., Mohanty, C.S., Pushpangadan, P., Singh, A., 2005. Stakeholder-based SWOT analysis for successful municipal solid waste management in Lucknow, India, Waste Manage. 25, 531-537.

Tabasová, A., Kropáč, J., Kermes, V., Nemet, A., Stehlík, P., 2012. Waste-to-energy technologies: Impact on environment, Energy 44, 146-155.

Talyan, V., Dahiya, R.P., Sreekrishnan, T.R., 2008. State of municipal solid waste management in Delhi, the capital of India, Waste Manage. 28, 1276-1287. doi: 10.1016/j.wasman.2007.05.017.

Timarpur Okhla Waste Management Company Pvt Ltd, 2011. Available at: http://towmcl.com/index.aspx (Accessed 8th March 2016).

Tsai, W.T., Chou, Y.H., 2006. An overview of renewable energy utilization from municipal solid waste (MSW) incineration in Taiwan, Renewable and Sustainable Energy Reviews 10, 491-502. doi: http://dx.doi.org/10.1016/j.rser.2004.09.006.

Unnikrishnan, S., Singh, A., 2010. Energy recovery in solid waste management through $\mathrm{CDM}$ in India and other countries, Resour. Conserv. Recycling 54, 630-640.

Veolia, 2014. Tyseley ERF. Available at: http://veolia.co.uk/our-services/ourservices/recycling-and-waste-services/facilities (Accessed 8th March 2016).

Veolia, 2012. Annual performance report for VESB Tyseley ERF.

Wolfe, J.M., Mahadevia, D., 2008. Solid Waste Management in Indian Cities: Status and Emerging Practices. Concept Publishing Company. 
World Energy Council, 2103. World Energy Resources: Waste to Energy. Available at: http://www.worldenergy.org/wpcontent/uploads/2013/10/WER_2013 7b Waste to Energy.pdf (Accessed 8th March 2016).

Yang, N., Zhang, H., Shao, L., Lü, F., He, P., 2013. Greenhouse gas emissions during MSW landfilling in China: Influence of waste characteristics and LFG treatment measures, J. Environ. Manage. 129, 510-521.

Zhuang, J., Gentry, R.W., Yu, G., Sayler, G.S., Bickham, J.W., 2010. Bioenergy sustainability in China: potential and impacts, Environ. Manage. 46, 525-530. 